\title{
The twilight of neoliberal globalization
}

\author{
Grigory S. Sergeev \\ Lomonosov Moscow State University, e-mail: sergeev_gs@mail.ru
}

Citation: Sergeev, G. S. (2020). The twilight of neoliberal globalization. Terra Economicus, 18(4), 67-77. DOI: 10.18522/2073-6606-2020-18-4-67-77

The author employs contemporary Marxist theory and methodology, and its theoretical concept of finance monopoly capital in particular, to analyze the decline of the neoliberal globalization currently under way. The paper shows that offshoring and financialization that developed during the neoliberal era have reinforced monopolistic dominance by mature imperialist states (namely, the "triad" of USA, EU and Japan), leading to the new division (or recolonization) of the periphery. As a result, the geo-economic space has become rigidly structured in a hierarchy of the groups of nations, with production having become increasingly organized within global production networks controlled by transnational corporations based in the "triad". However, mass transfer of the labor-intensive industries to low-wage countries of the periphery, and to China in particular, has resulted in geopolitical and economic rise of the latter, thus intensifying competition and struggle between national imperialisms. Deglobalization that emerged and evolved during the post-crisis period appears as a manifestation of a new redivision of the world, with unfolding redrawing of the geoeconomic map, creeping degradation of supranational institutions and spike of trade wars between the world's largest economies.

Keywords: neoliberal globalization; transnational corporations; finance monopoly capital; global production networks; offshoring; financialization; deglobalization; imperialism

JEL codes: B51, F54

(C) Г.С. Сергеев, 2020 


\title{
Закат неолиберальной глобализации
}

\author{
Григорий Сергеевич Сергеев
}

МГУ им. М.В. Ломоносова, e-mail: sergeev_gs@mail.ru

Цитирование: Sergeev, G. S. (2020). The twilight of neoliberal globalization. Terra Economicus, 18(4), 67-77. DOI: 10.18522/2073-6606-2020-18-4-67-77

В статье анализируется происходящий в настоящее время закат неолиберальной глобализации. Используя теоретико-методологический аппарат современного марксизма $u$, в частности, концепцию финансового монополистического капитала, автор показывает, что результатом офшоризации и финансиализации как важнейших характеристик неолиберальной эпохи стало монополистическое господство «старых» империалистических держав (а именно «триады» США, ЕС и Японии), что привело к новому разделу (или реколонизации) экономического пространства периферии. В результате геоэкономическое пространство оказалось жестко структурировано в соответствии с иерархически выстроенной глобальной системой производства в форме глобальных производственных сетей, которые контролируются транснациональными корпорациями, базирующимися в странах «триады». 0днако массовый перенос трудоемких производств в страны периферии с низким уровнем оплаты труда, в частности, в Китай, привел к геополитическому и экономическому подъему последних, что усилило конкуренцию и борьбу между национальными империализмами. Тем самым процесс деглобализации, развернувшийся в посткризисный период, является формой нового передела мира, сопровождающегося расколом геоэкономического пространства, ползучей деградацией наднациональных институтов и всплеском торговых войн между крупнейшими экономиками мира.

Ключевые слова: неолиберальная глобализация; транснациональные корпорации; финансовый монополистический капитал; глобальные производственные сети; офшоризация; финансиализация; деглобализация; империализм

\section{Introduction}

Amid global economic fallout of the coronavirus crisis in June 2020, BlackRock Inc. and Bridgewater Associates both went so far as to warn that globalization had already peaked and decades of globalization would erode. Even earlier, in his Sberbank Business Lunch address ${ }^{1}$ in Davos in January 2019, CE0 of the Russian Nanotechnology Corporation (RUSNAN0) Anatoly Chubais argued that the deglobalization process currently under way points to a fundamental shift in the existing world order. His suggested term for that shift was "a crisis of the liberalism"2. One can hardly disagree with this assessment by the principal beneficiaries of the neoliberal era $^{3}$ and by one of the chief ideologists of the neoliberal reforms in Russia ${ }^{4}$, namely with their concrete "diagnosis" for the condition of present-day global capitalist system.

The current spike of protectionist trade wars among leading centers of global economy, creeping degradation of the supranational institutions, and the overall rise in geopolitical confrontation, all point to a structural crisis of the global capitalism, which throws an already declining neoliberal

\footnotetext{
1 The event had a telling subtitle, "Doing Business in the (De)Globalized World". PJSC Sberbank is the largest Russian transnational financial conglomerate and is \#402 on the Forbes 2020 Global 2000. The bank holds about a third of all banking assets in Russia and about $1 / 2$ of all private bank deposits in that country. It has branches in over 20 countries, including CIS, Central and Eastern Europe, and Turkey.

Sberbank Business Lunch at Davos Forum (https://www.youtube.com/watch?v=YdEvMs64ba0).

3 BlackRock Inc. is the world's largest investment fund with $\$ 7.4$ trillion in assets under management and is \#177 on the Forbes 2020 Global 2000. Privately held Bridgewater Associates is the world's largest hedge fund.

4 A key member on the team of Russia's "young reformers" (whose earlier parallel were the "Chicago boys" in Chile), Chubais was responsible for implementing the program of neoliberal "shock therapy" reforms in Russia during the early 1990s.
} 
globalization into a tailspin. Qualitative changes in the reproduction system of the late capitalism ${ }^{5}$ increasingly resemble a remarkable transformation of the world order that has taken place in a form of imperialism from around the turn of the previous century. In this respect, it is not surprising that, as Desai noted, "postwar developments made ... the classical theories of imperialism more, not less, relevant" (Desai, 2013: 88).

This paper attempts to prove that contemporary Marxist theory is relevant in providing a sound theoretical framework that can successfully explain the principle developments in the global capitalist economy during the neoliberal period. These are: how offshoring and financialization that developed during the neoliberal globalization reinforce monopolistic dominance by mature imperialist states (namely, USA, EU and Japan) on the one hand and lead to the geopolitical and economic rise of China and other fast-growing economies on the other, and how, on this basis, deglobalization emerges and evolves.

\section{Finance monopoly capital as a theoretical starting point}

Until recently, the reigning paradigm has been a neoclassical economics whose positivist theoretical framework encourages to empirically register facts and develop mathematical models thereon rather than to look into the nature of social relations underlying the "internal physiology" of the facts floating on the surface (Porokhovsky, 2016: 20). However, the global economic crisis of 2007-2009, which for neoliberal economists was certainly impossible to actually materialize ${ }^{6}$, proved that neoclassical theory no longer responds adequately to the accumulated problems of the existing world order.

Given a thorough internationalization of the production process, one cannot view the contemporary system of capitalism "as a mere aggregation of national economies, to be analyzed simply in terms of the gross national products (GDPs) of the separate economies and the trade and capital exchanges occurring between them" (Suwandi et al., 2019). The urgent need to make sense of the "organic whole" of the global capitalism today, including all of its specific features and contradictions as these emerged in the context of historical shifts and development, pushes the scholars towards a critical rethinking and engagement of classical Marxist political economy, along with post-Keynesianism, institutional economics, world-system analysis and other heterodox economic theories, into the mainstream academic discourse.

A number of books by heterodox economists have been published during the post-crisis period on global capitalism. These are (Amin, 2010), (Cope, 2012), (Desai, 2013), (Harvey, 2014), (Krugman, 2009), (Kotz, 2015), (Panitch, Gindin, 2013), (Patnaik, Patnaik, 2017), (Screpanti, 2014), (Smith, 2016). Among Russian scholars, we shall highlight the representatives of the post-Soviet School of Critical Marxism Buzgalin and Kolganov who argue that the global capitalism, at its neoliberal stage, is currently restoring, in a new form, many features of the late capitalism at the beginning of the twentieth century (Buzgalin et al., 2016: 647).

At the turn of the twentieth century, the classical Marxist theorists famously saw free competition capitalism moving into a qualitatively new stage of monopoly capitalism associated with domination of finance monopoly capital in the leading national economies (Hilferding, 1981; Lenin, 1974). For instance, Lenin's reading was that the reign of monopolies and of finance monopoly capital within the sphere of social and economic relations represented a key feature or a "germcell" of imperialism. His succinct definition for imperialism was therefore "the monopoly stage of capitalism" (Lenin, 1974: 266). The economic and political carving of "aboriginal lands" by the great imperialist powers at the turn of the twentieth century was a result of monopoly domination and is

\footnotetext{
We use the term "late capitalism" to refer to "a stage when a sprout of post-market relations emerges within capitalism; these relations deny the quality and the very nature of capital, yet at the same time they propel capitalism to develop further" (Buzgalin, Kolganov, 2015: 17).

6 Suffice it to say, in the early 2000s, Robert Lucas and Ben Bernanke, leading representatives of the mainstream of the U.S. economics profession, both were incredibly optimistic to declare that the depression-prevention problem had been solved, "for all practical purposes" (Krugman, 2009: 9-10). It is not surprising that, according to such orthodox neoclassical scholars, there are no objective grounds for a crisis to occur under capitalism, meaning "the crisis is caused not by the market, but by people taking wrong decisions" (Ryazanov, 2015: 57).
} 
thus to be viewed as "geo-economic and geopolitical sine qua non of monopoly capital" (Buzgalin, Kolganov, 2015: 36).

Russian economists further developed theoretical concept of finance monopoly capital during the Soviet period. For instance, in his analysis of the state monopoly capitalism of the mid-1980s, Porokhovsky (1985: 49) noted that gigantic socialization of production immanent for capitalist mode of production on the one hand and relations of finance capital inevitably penetrating into every sector of public life on the other anchored the monopolistic dominance of the mature imperialist nations.

It is important to note that the contemporary neoliberal era began as a response to the crisis of the "regulated capitalism" (Kotz, 2018: 9). A significant redistribution of the surplus value toward labor, which by the start of the 1970s became the hallmark in the leading capitalist economies, created a threat that "a qualitative revolutionary change of the very fundamentals of the capitalist system may occur" (Buzgalin, Kolganov, 2015: 44). Big business responded by demoting the Keynesianism and the idea of welfare state, and neoliberalism went through a renaissance, with monetarism having become the new orthodoxy both in economic theory and in practice. Subsequent transition to an open model of global labor and capital markets, alongside weakening of nation-state's regulation, facilitated internationalization of economic links, which led to a rapid growth of transnational corporation (TNC) as a leading form of monopoly capital today.

We shall further elaborate by showing how the offshoring and financialization, as distinguishing features of neoliberal globalization, have reinforced monopoly dominance of the mature imperialist nations, leading to the division of the periphery's economies. In doing so, we shall also gain a clearer view of the aforementioned phenomenon of deglobalization.

\section{Neoliberal globalization as a division of the world}

One should remember that the chief outcome of the freeing-up of the market forces during the 1970s was a gigantic socialization of production in a form of global production networks. Mass transfer of labor-intensive industries from the developed nations to low-wage countries resulted in the globalized system of offshoring ${ }^{7}$. Global capitalism thus polarized the geo-economic space into Southern "production economies" and Northern "consumption economies" (Cope, 2012).

UNCTAD estimates that up to 80 per cent of today's global trade runs through global production networks controlled by transnational giants representing the advanced capitalist core (UNCTAD, 2013: 135). Moreover, up to two thirds of global trade belongs to intermediate goods and services that are used at various stages of the production cycle within global production networks. In other words, export and import of manufactured goods no longer represent "trade". Instead, they are rather part of a product flow within global production networks subject to control by TNCs of the most developed nations.

It is extremely important to note that super-profits from offshoring became a principal source of financialization, which refers to "the increase in activity in financial markets, a rise in the value of financial assets, an increase in foreign exchange transactions compared to the volume of international trade, and other indicators of financial activity" (Kotz, 2017: 33). Offshoring-financialization interdependence resulted in non-financial corporate sector having behaved "increasingly like the financial sector, purchasing more financial assets and raising dividends and executive compensation rather than investing in the real economy" (Milberg, Winkler, 2013: 237). To put it another way, financialization, along with significant progress in productive forces and in information and communication technology in particular, has expanded and deepened the dominance of the finance capital, making the latter as mobile, virtual and truly globalized as possible.

Super-profits thus reaped by TNCs from the super-exploitation of labor-power in the Third World, along with significant portion of surplus value transferred from (semi-)periphery to capitalist core due to finance capital domination of the latter, comprise a solid base of a good health of a capitalist core, which Amin has christened their "imperialist rent" (Amin, 2010).

\footnotetext{
Offshoring is defined as "all purchases of intermediate inputs from abroad, whether done through arm's-length contract - offshore outsourcing - or within the confines of a single multinational corporation (MNC) - intra-firm trade" (Milberg, Winkler, 2013: 2).
} 
Furthermore, state deregulation policy and liberalization of international relations achieved a tremendous concentration of capital in the hands of the largest corporations from a select group of the advanced capitalist economies. In 1987-1999, the volume of cross-border mergers and acquisitions increased tenfold, to $\$ 720$ billion per annum; it remains at approximately the same level today (UNCTAD, 2000, 2018). The result of that cross-border expansion was a significant increase in the foreign assets of TNCs: 24 times in 26 years, from $\$ 4.6$ trillion in 1990 to $\$ 112.8$ trillion in 2016. It is noteworthy that, for the year 2016, among the top 100 non-financial TNCs with combined foreign assets of $\$ 9$ trillion, the share of corporations from OECD countries was 96 per cent ( $\$ 8.6$ trillion); for the corporations from the five mature imperialist countries (USA, UK, Germany, France, and Japan), that figure was 72 per cent ( $\$ 6.5$ trillion). By way of comparison, the combined foreign assets of the top 100 non-financial TNCs from the developing world was $\$ 1.9$ trillion, for that same year. Without China, the figure was $\$ 958$ billion, which is roughly equal to the combined foreign assets of just three largest TNCs from the capitalist "core": British and Dutch ROYAL DUTCH SHELL, Japanese TOYOTA, and French TOTAL (UNCTAD, 2017).

In fact, the neoliberal globalization, the advancement of which benefited greatly from the collapse of the global socialist system at the end of the 1980s and the early 1990s, appeared as a form of economic division (or recolonization) of the periphery among the giant monopolistic corporations of the capitalist core (namely, the "triad" of USA, EU, and Japan). This manifested and reinforced monopolistic dominance by the transnational financial and industrial corporations, meaning that the latter acquired total control over global trade, industrial manufacturing, financial flows, as well as research and development ${ }^{8}$.

As Hobson wrote at the turn of the twentieth century, "(e)very advanced industrial nation is tending to place a larger share of its capital outside the limits of its own political area, in foreign countries, or in colonies, and to draw a growing income from this source" (Hobson, 1902: 56-57). Later, Lenin elaborated that "(t)he capitalists divide the world, not out of any particular malice, but because the degree of concentration which has been reached forces them to adopt this method in order to obtain profits" (Lenin, 1974: 253). Today the geo-economic space appears to be structured based on a hierarchy of the groups of nations within global production system represented in Table 1.

The Geo-Economic Map of Global Capitalism

\begin{tabular}{|c|c|c|}
\hline Group of nations & $\begin{array}{c}\text { Basic description and the } \\
\text { corresponding economy model }\end{array}$ & Leading nations \\
\hline $\begin{array}{c}\text { Center } \\
\text { (aka North, or Capitalist } \\
\text { Core) }\end{array}$ & $\begin{array}{c}\text { The force behind global hegemony of } \\
\text { capital; they lead in the transition to } \\
\text { postindustrial capitalism by exploiting } \\
\text { the (semi)periphery's labor-power and } \\
\text { natural resources }\end{array}$ & $\begin{array}{c}\text { Advanced imperialist } \\
\text { powers led by the USA }\end{array}$ \\
\hline $\begin{array}{c}\text { Semi-periphery } \\
\text { (Industrial South) }\end{array}$ & $\begin{array}{c}\text { Developing countries in the process of } \\
\text { "catch-up" growth of dependent type; } \\
\text { economy model is based on export- } \\
\text { oriented industrialization }\end{array}$ & $\begin{array}{c}\text { Large new industrial } \\
\text { economies led by } \\
\text { China }\end{array}$ \\
\hline $\begin{array}{c}\text { Periphery } \\
\text { (South, or Third World) }\end{array}$ & $\begin{array}{c}\text { Underdeveloped countries in the process } \\
\text { of dependent growth; economy model is } \\
\text { based on export of raw materials }\end{array}$ & $\begin{array}{c}\text { Large suppliers of } \\
\text { energy resources (e.g., } \\
\text { Saudi Arabia) }\end{array}$ \\
\hline
\end{tabular}

Source: prepared by the author based on (Buzgalin, Kolganov, 2015: 614).

\footnotetext{
In 2017, 10 per cent of global GDP and 1/3 of global exports were the share of TNCs foreign affiliates. The transnational giants proper controlled over 50 per cent of global industrial production and 80 per cent of global trade (UNCTAD, 2017). As Harvey put it, "the current situation in many sectors of the economy (pharmaceuticals, oil, airlines, agribusiness, banking, software, the media and social media in particular, and even box retailing) suggests strong tendencies towards oligopoly if not monopoly" (Harvey, 2014: 136).
} 


\section{Deglobalization under way}

Extended interlocking, or "coalescence", of national imperialisms into a global finance monopoly capital during the neoliberal era amid the unprecedented growth of cross-border activity by the largest corporations intensified by the collapse of global socialist system at the turn of 1990s gave rise to the phenomenon of "collective imperialism" (Amin, 2010: 29). Once this is recognized, it may become apparent that "it is globalized finance capital, of which the finance capitals of individual countries are component parts and which does not belong to any particular country, operating all over the globe" (Patnaik, Patnaik, 2017: 5).

However, the global economic crisis of 2007-2009 during which nation-states lavishly spent their taxpayers' money in order to rescue some of their affiliated financial and industrial corporations broke a globalist illusion that finance monopoly capital has finally severed connection with nation-state.

Moreover, acceleration of globalization processes has stumbled in the aftermath of the world economic crisis of 2007-2009, and the intensity of global trade and investment has been on a consistent decline ever since.

During the first few years after the crisis, the annual rate of growth for global trade was lower than the rate of growth for global GDP. By way of comparison, between mid-1980s and 2008, the former was almost twice as large as the latter, on average (see Fig. 1).

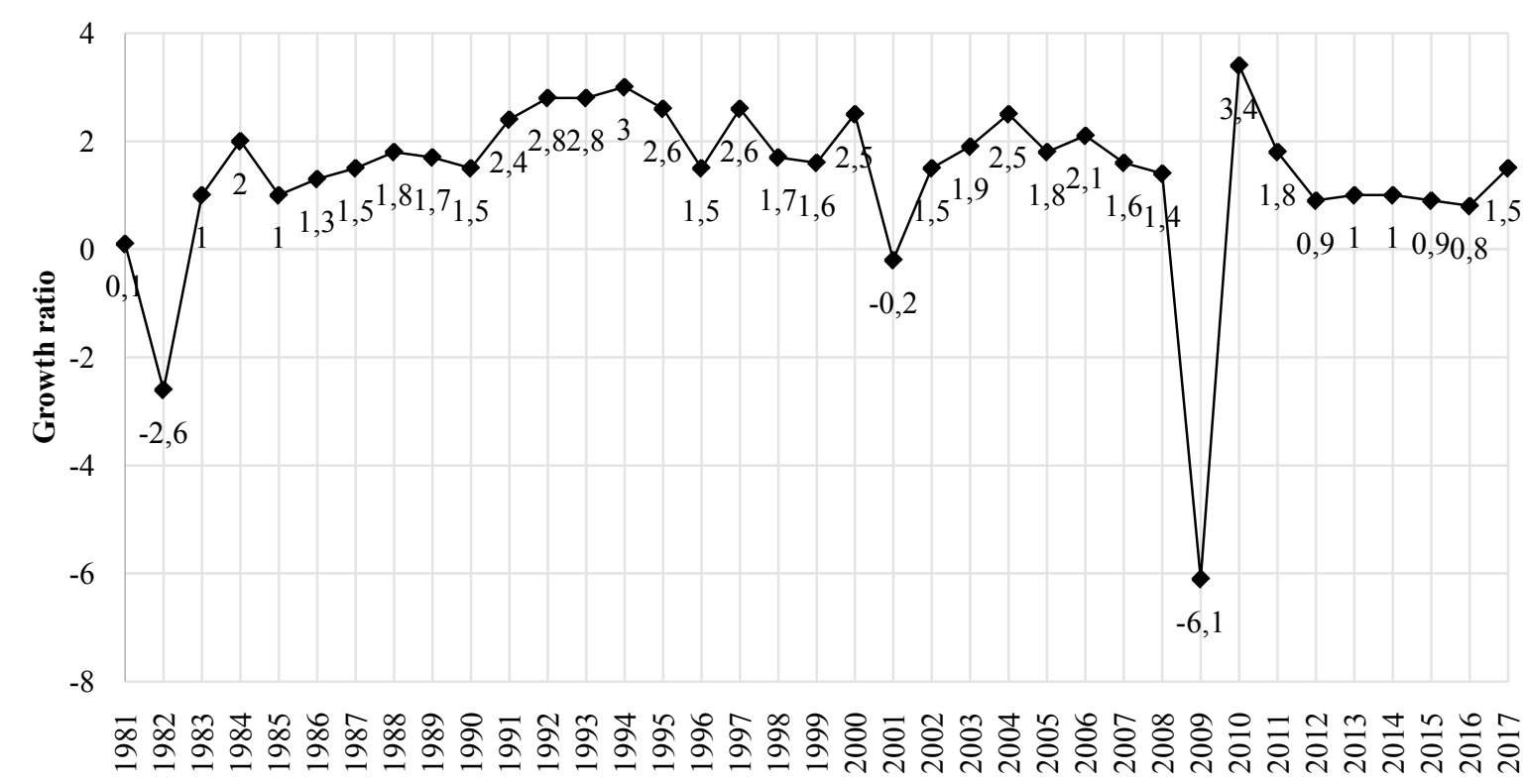

Fig. 1. Ratio of world merchandise trade volume growth to world real GDP growth, 1981-2016

Source: prepared by the author based on data in (WT0, 2017).

Since 2008, the value of announced FDI greenfield projects (an indicator of future FDI flows) has been on a consistent decline. By 2017, FDI has reached the bottom level of $\$ 720$ billion, which was lower compared to the decade before. During the entire post-crisis period, FDI rates of return continued to decline in the developed and the developing nations alike (UNCTAD, 2018).

A small recovery growth of 2010 excepting, for the entire post-crisis period of 2009-2017 the volume of global capital flows has remained flat at 5-7 per cent of global GDP. One should note that, in the period before the crisis, the threefold growth of cross-border capital flows against the global GDP (namely, from 7.5 per cent in 2002 to 21.4 per cent in 2007) owed largely to the outrunning growth of bank loans (UNCTAD, 2018).

According to UNCTAD, stagnation of international production and global production networks during 2010s was only "the quiet before the storm". Along with replication and diversification, the currently emerging trends of reshoring and regionalization "point to a retreat of international production", meaning "dramatic transformation" over the coming decade (UNCTAD, 2020: 156). 
There is a tone anxiety in what the representatives of international financial and economic institutions are saying today about the expanding crisis of globalization ${ }^{9}$. For example, Agustín Carstens, General Manager of the Bank for International Settlements (aka "central bank of central banks"), has voiced alarm over "recent measures to reverse globalization and to retreat into protectionism". As Carstens has put it, various "real and financial risks" associated with such measures "could amplify each other, creating a perfect storm and exacting an even higher price" (Carstens, 2018: 1).

The failure of talks on the WTO Doha Round may evidence that supranational institutions are becoming increasingly obsolete, i.e., they no longer possess the ability to steer the global economy by adjusting the mechanisms of international economic relations. For example, in his televised remarks to the 2019 World Economic Forum in Davos, U.S. Secretary of State Mike Pompeo has openly declared that trade talks between his country and others should occur within a bilateral framework rather than a multilateral one (like WTO, IMF, or WB). He added that "this disruption (to economic globalization) is a positive development ... No international body can stand up for a people as well as their own leaders can" (Pompeo, 2019).

A spike of protectionism and emergence of trade wars both have aggravated the post-crisis "new normalcy". During 2017 G20 imposed over 1,200 non-tariff measures; this was a four-time increase compared to 2010 (Carstens, 2018: 2). Global Trade Alert data confirms this global protectionist trend: from 2010 to 2018 the number of protectionist measures implemented by national governments in the fields of trade, investment, and migration, has grown twice (see Fig. 2).

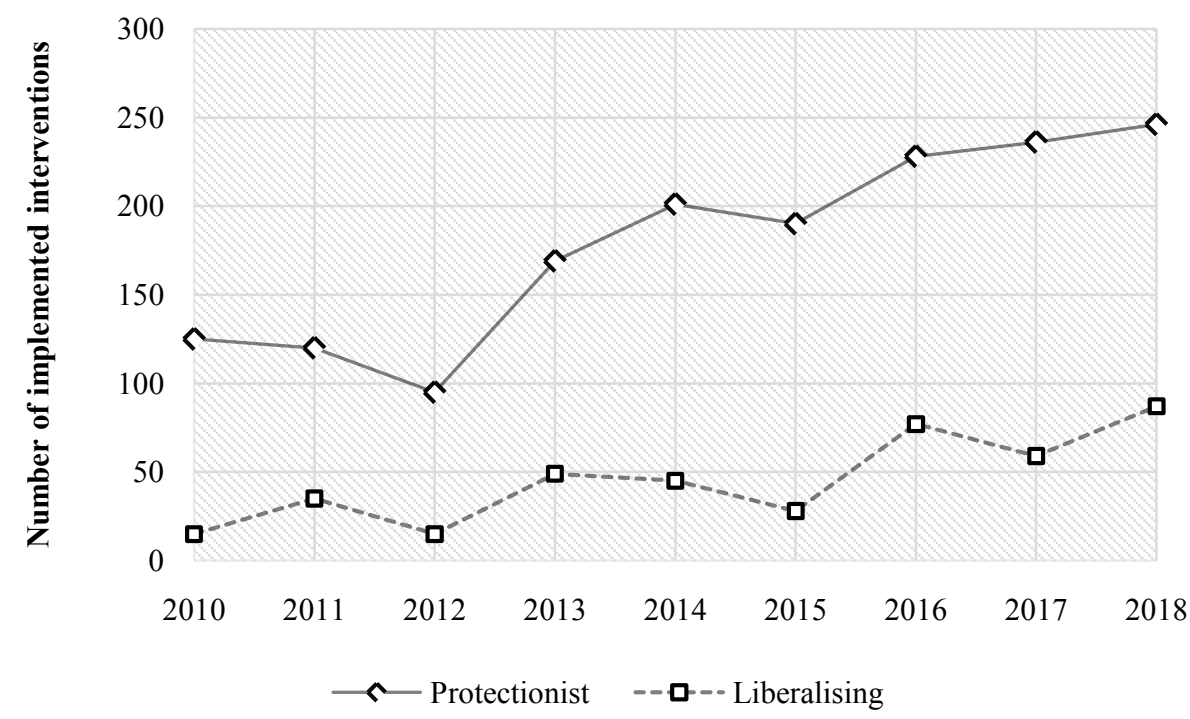

Fig. 2. New interventions implemented by governments in global trade, investment and migration, 2010-2018

Source: prepared by the author based on data in (Global Trade Alert, 2019).

In our view, the most distinguishing feature of deglobalization today is the splitting and fragmentation of the geo-economic space. One can observe a dramatic rise in competition among "the blocks of countries whose combined economic potential makes it easier for them to affect the conditions of global economy" (Hubiev, 2017: 63). For example, when China moved to redraw the global economic and trade routes by introducing "One Belt One Road" initiative in 2013, US and EU responded by actively promoting their own projects, most notably the Trans-Pacific Partnership and the Transatlantic Trade and Investment Partnership.

\footnotetext{
As a result of the neoliberal version of globalization, these institutions have successfully built themselves into independent "supra-national" structures whose main job, in the final run, is to serve the interests of the global corporate and bureaucratic elite, the representatives of a so-called "transnational capitalist class" (Sklair, 2016).
} 


\section{A new redivision of the world?}

It is noteworthy that the ultra-low wages were not the only determining factor for the inclusion of the developing countries of the periphery into the TNCs production processes. Another key factor was the ability of national comprador bourgeoisie supported by government bureaucracies to maintain, during a foreseeable period of time and by repressing class and social protests, low wages and to ensure significantly low, if compared to imperialist nations, social security, labor safety and environmental standards. It is for this reason that export-oriented industrialization based on labor-intensive technologies worked in the economies with strong authoritarian rule and disciplined labor-power (the countries of South and South East Asia, in particular).

Specifically, a combination of the above factors enabled the rise of China. With the start of the project of "reform and openness", the leadership of China steered the transition to capitalism by facilitating the integration of the Chinese economy into world capitalist system (Li, 2008. P. 107) ${ }^{10}$.

During the last forty years, the mature imperialist powers with USA at the top have been the main beneficiaries of the free trade globalization wave. However, today these nations are increasingly resisting further liberalization of the global economy as they rightly fear the continuing strengthening of the geo-economic position of China as well as some other fast-growing economies. Jagdish Bhagwati, one of the best-known apologists of the neoliberal version of globalization ${ }^{11}$, argued that, in the aftermath of WWII, the most sensitive blow to the multinational global trade system has come from none else but USA and EU (Bhagwati, 2013: 11).

The sharpening of a contradiction between the increasing role of China and other semiperipheral nations that are attempting to flex their economic muscles globally on the one hand and their enforced subordination to the finance monopoly capital of the mature imperialist powers on the other, pushes for a new redivision of the world, with a deglobalization under way being its symptom. The principal manifestations of deglobalization, as we have already shown, are the split of the geo-economic map, creeping degradation of supranational institutions, and in particular the current spike of protectionist U.S.-Sino trade war, which superficial observers still frequently regard as a mere consequence of Trump's populist internal politics and of certain xenophobia in the United States. Contemporary global imperialism is thus in no way "a system of control of the world economy without substantial inter-imperial contradictions" (Screpanti, 2014: 52).

One should remember that the economic and political redivision of the world in the early twentieth century resulted in two world imperialist wars, which appeared to be a "natural" way of resolving inter-imperialist contradictions. Deepening conflicts between leading economies are trailed by the growing military spending (see Fig. 3). It is noteworthy that, during the boom phase of globalization in 1990s, the total global military spending saw a decrease of over 30 per cent when compared to numbers at the peak of Cold War (mid-1980s); the historical minimum was reached in 1998 (\$994 billion). One can explain this dramatic decrease not only by the plummeting military spending across the countries of the former Soviet Union following its collapse in $1991^{12}$, but by a drastic cut in US military spending as well (namely, by 32 per cent).

Nonetheless, during the following decade of 1999-2008, the total global military spending rose 1.5 times, to $\$ 1.6$ trillion, which was 10 per cent higher than in 1988 . While the recent global economic crisis witnessed a drop across the entire range of economic indicators, it in no way affected military spending figures; in 2009, these figures rose by $\$ 100$ billion. Also, while the total global military spending remained more or less flat during the entire post-crisis decade, the share of the US in that spending decreased by 10 per cent, from 45 per cent in 2007 to 35 per cent in 2017. This evidences that military spending of other geopolitical actors, especially China, have bloated up. China's military spending rose sevenfold in the period from 1998 to 2017 , up to $\$ 228$ billion, or 13.5 per cent of the total global military spending in 2017.

\footnotetext{
10 In 2013, global production networks employed 453 million people and 39.2 per cent were workers in China (Foster, 2015).

11 See, for example, (Bhagwati, 2004).

12 In 1998, the military spending of the former USSR countries dropped nearly 15 times compared to 1988 .
} 


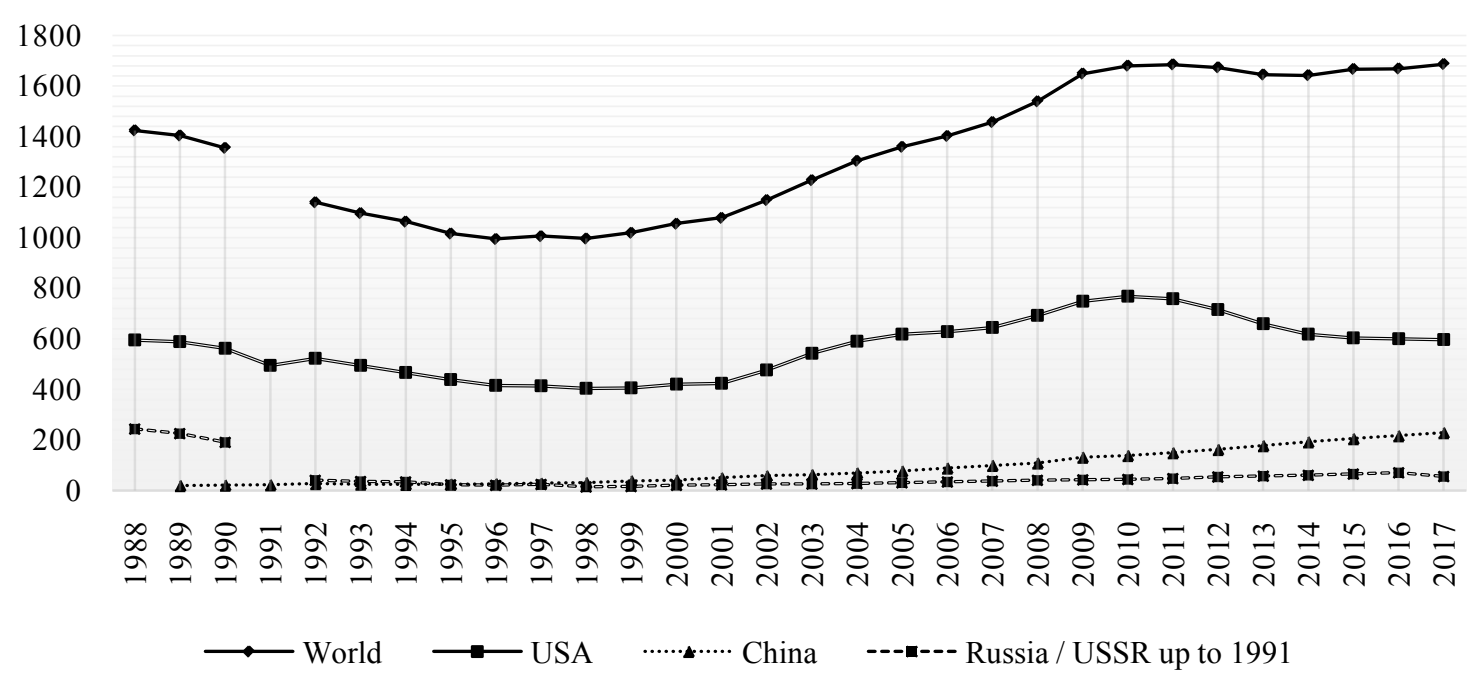

Fig. 3. Military spending ( $\$$ billion), 1988-2017

Source: prepared by author based on data in (SIPRI, 2019).

Note: the data for the world and USSR/Russia military spending for 1991 were not available.

Today, the flood of publications and media discussions voicing a threat of a new global war is a major source of concern ${ }^{13}$. Leading nuclear-armed states have added a nuclear strike option to their national defense doctrines and other such documents, be it a limited nuclear strike option or a comprehensive one (Erästö, Cronberg, 2018).

\section{Conclusion}

In his analysis of the mid-nineteenth-century capitalism, Marx noted that "(t)he capitalist mode of production is ... a historical means of developing the material forces of production and creating an appropriate world-market and is, at the same time, a continual conflict between this its historical task and its own corresponding relations of social production" (Marx, 1961: 274).

As the monopoly capital expanded during the last quarter of the twentieth century, with neoliberal globalization having accelerated this process multiple times, individual economic localities came together and formed a discordant global market. At the same time, science became a productive force of direct nature. Nevertheless, the objective logic of late-capitalist development has created a situation when, similar to one hundred years ago, one finds global market conquered and carved by the largest multinational corporations whose hegemony is based on their "economic power merged with the political power of the state" (Hubiev, 2017: 66).

Global capitalism thus continues to reproduce the center-periphery model of power-driven exploitation and oppression of weaker nations, which was a dominant feature of the imperialist relations of production one century ago. As Lenin wrote at that time, "Domination, and the violence that is associated with it ... has resulted from the formation of all-powerful economic monopolies" (Lenin, 1974: 207). One can hardly overestimate the continuing relevance of this statement.

The slowdown of globalization and the unfolding redrawing of the geo-economic map both point to the historical and geographic limits that the late capitalism has reached in terms of growth and development. What has been specifically exhausted is continuing accumulation of capital by means of including new "indigenous lands" into the purview of the world capitalist economy. As a result, global economic space is currently reshaping, and the "national imperialisms" are beginning to compete and struggle with one another, similarly to what we witnessed at the start of the twentieth century.

\footnotetext{
${ }^{13}$ For example, in April 2017, Google searches for "World War 3" have spiked to a record high (available at: https://ria. $\mathrm{ru} / 20170414 / 1492279438 . \mathrm{html})$.
} 


\section{References}

Amin, S. (2010). The Law of Worldwide Value. New York: Monthly Review Press.

Bhagwati, J. (2004). In Defense of Globalization. 0xford: 0xford University Press.

Bhagwati, J. (2013). Dawn of a New System. Finance and Development, 50(4), December, pp. 8-13.

Buzgalin, A. V., Kolganov, A. I. (2015). Global Capital, vol. 2. Theory: Global Hegemony of Capital and Its Limits ('Capital' Reloaded). Moscow: LENAND Publ. (In Russian.)

Buzgalin, A., Kolganov, A., Barashkova 0. (2016). Russia: A New Imperialist Power? International Critical Thought, 6(4), 645-660.

Carstens, A. (2018). Global Market Structures and the High Price of Protectionism. Overview panel remarks. Bank of International Settlements (https://www.bis.org/speeches/sp180825.pdf).

Cope, Z. (2012). Divided World Divided Class, Global Political Economy and the Stratification of Labour Under Capitalism. Montreal: Kersplebedeb.

Desai, R. (2013). Geopolitical Economy: After US Hegemony, Globalization and Empire. London: Pluto.

Erästö, T., Cronberg, T. (2018). Opposing trends: The renewed salience of nuclear weapons and nuclear abolitionism. SIPRI Insights on Peace and Security (https://www.sipri.org/publications/2018/ sipri-insights-peace-and-security/opposing-trends-renewed-salience-nuclear-weapons-andnuclear-abolitionism).

Foster, J. (2015). The new imperialism of globalized monopoly-finance capital. Monthly Review (https://monthlyreview.org/2015/07/01/the-new-imperialism-of-globalized-monopolyfinance-capital/).

Global Trade Alert. New Interventions per Year (https://www.globaltradealert.org/global_dynamics/ day-to_0417/flow_all).

Harvey, D. (2014). Seventeen Contradictions and the End of Capitalism. New York: Oxford University Press.

Hilferding, R. (1981). Finance Capital: A Study of the Latest Phase of Capitalist Development. London: Routledge and Kegan Paul.

Hobson, J. A. (1902). Imperialism. A Study. London: James Nisbet \& Co.

Hubiev, K. (2017). Contemporary trends in the world economic development: Political economy approach. Problemy Sovremennoy Ekonomiki, (1), 62-67. (In Russian.)

Kotz, D. M. (2015). The Rise and Fall of Neoliberal Capitalism. Harvard University Press.

Krugman, P. (2009). The Return of Depression Economics and the Crisis of 2008. New York: W.W. Norton and Company.

Lenin, V. I. (1974). Imperialism, The Highest Stage of Capitalism / In: Collected Works, vol. 22. Moscow: Progress Publishers.

Li, M. (2008). The Rise of China and the Demise of the Capitalist World-Economy. London: Pluto Press.

Marx, K. (1961). Capital, vol. III / In: Marx, K., Engels, F. Collected Works, vol. 25, part 1. Moscow: Politizdat Publ. (In Russian.)

Milberg, W., Winkler, D. (2013). Outsourcing Economics: Global Value Chains in Capitalist Development. Cambridge: Cambridge University Press.

Panitch, L., Gindin, S. (2013). The Making of Global Capitalism: The Political Economy of the American Empire. Verso.

Patnaik, P., Patnaik, U. (2017). A Theory of Imperialism. New York: Columbia University Press.

Pompeo, M. (2019). Remarks to the World Economic Forum. US Department of State (https://www. state.gov/remarks-to-the-world-economic-forum/).

Porokhovsky, A. A. (1985). Big Business: Path to Domination (Imperialism and Commodity Relations). M.: Mysl Publ. (In Russian.) 
Porokhovsky, A. A. (2016). Political economy in the XXI century: System approach to the problem solving in the contemporary economy. Voprosy Politicheskoy Ekonomii, (4), 8-22. (In Russian.)

Ryazanov, V. T. (2015). Capitalism and crises. Genesis and development of political economy approach. Voprosy Politicheskoy Ekonomii, (1), 48-53. (In Russian.)

Screpanti, E. (2014). Global Imperialism and the Great Crisis: The Uncertain Future of Capitalism. Monthly Review Press, 288 p.

SIPRI Military Expenditure Database. Stockholm International Peace Research Institute (https:// sipri.org/databases/milex).

Sklair, L. (2016). The transnational capitalist class, social movements, and alternatives to capitalist globalization. International Critical Thought, 6(3), 329-341.

Smith, J. (2016). Imperialism in the Twenty-First Century: The Globalization of Production, SuperExploitation, and Capitalism's Final Crisis. Monthly Press Review.

Suwandi, I., Jonna, J., Foster, J. (2019). Global Commodity Chains and the New Imperialism. Monthly Review, 70(10) (https://monthlyreview.org/2019/03/01/global-commodity-chains-and-thenew-imperialism/).

UNCTAD (2000). World Investment Report (http://unctad.org/en/docs/wir2000_en.pdf).

UNCTAD (2013). World Investment Report (https://unctad.org/en/PublicationsLibrary/wir2013_ en.pdf).

UNCTAD (2017). World Investment Report (https://unctad.org/en/PublicationsLibrary/wir2017_ en.pdf).

UNCTAD (2018). World Investment Report (https://unctad.org/en/PublicationsLibrary/wir2018_ en.pdf).

UNCTAD (2020). World Investment Report (https://unctad.org/en/PublicationsLibrary/wir2020_ en.pdf).

WTO (2017). World Trade Statistical Review (https://www.wto.org/english/res_e/statis_e/ wts2017_e/wts17_toc_e.htm). 